\title{
The Use of Entrepreneurship Education in Community Empowerment at Lintangsongo Islamic Boarding School of Yogyakarta
}

\author{
Muhammad Roy Purwanto, Supriadi, RahmaniTimoritaYulianti
}

\begin{abstract}
This paper discusses entrepreneurship education at Lintang Songo Islamic Boarding School which is taught to students and the surrounding community. Islamic boarding schools are the oldest educational institutions with unique and distinctive characteristics in Indonesia. It came into existence hundreds of years ago. According to historical records, the first Islamic boarding school in Indonesia was founded by Syeh Maulana Malik Ibrahim in 1399 AD to spread Islam on Java. Therefore, it has become a part of Indonesian education for a long time. Lintang Songo is one of such Islamic Boarding Schools that aims at surviving with consistency in carrying out its social functions. Furthermore, the uniqueness of its pesantren's activities and programs is associated with entrepreneurship education for students and society. This paper, therefore, discusses entrepreneurship education to improve the economy of students and society. This field research uses qualitative methods in analyzing data. Meanwhile, data obtained by observation, documentation and interviews. The informants of this study consisted of 12 people, from the head of the LintangSongo Islamic Boarding School, the teachers, students and the community. Several questions were asked to informants, such as what economic empowerment program was developed at LintangSongo Islamic Boarding School, why LintangSongo Islamic Boarding School developed economic empowerment education. The answers to these questions are then analyzed using qualitative methods. The results showed that LintangSongo Islamic Boarding School succeeded in economic empowering of its students and local communities with entrepreneurship education, which is taught as the curriculum of LintangSongo Islamic boarding school. Economic empowerment conducted by LintangSongo Islamic Boarding School for its students and community is agricultural empowerment, plantations, animal husbandry, forestry, fisheries, home industry, food, and convection.
\end{abstract}

Keywords: LintangSongo Islamic Boarding School, entrepreneurship, economy, empowerment of the community.

\section{INTRODUCTION}

Pesantren/Islamic boarding schools are traditional Islamic educational institutions that study, understand,

Revised Manuscript Received on December 30, 2019.

* Correspondence Author

Muhammad Roy Purwanto*, Faculty of Islamic Studies, Universitas Islam Indonesia, Yogyakarta, Indonesia. Email: muhammadroy@uii.ac.id

Supriadi, Faculty of Islamic Studies, Universitas Islam Indonesia, Yogyakarta, Indonesia. Email: supriadiofficial13@gmail.com

RahmaniTimoritaYulianti, Faculty of Islamic Studies, Universitas Islam Indonesia, Yogyakarta, Indonesia..Email: rahmanitimorita@uii.ac.id

(C) The Authors. Published by Blue Eyes Intelligence Engineering and Sciences Publication (BEIESP). This is an open access article under the CC BY-NC-ND license (http://creativecommons.org/licenses/by-nc-nd/4.0/) explore, appreciate, and practice Islamic teachings by emphasizing on the importance of religious morality as a guide to everyday life [1]. The word "traditional" indicates that this institution existed for hundreds of years. According to historical records, the first Islamic boarding school in Indonesia was founded by Syeh Maulana Malik Ibrahim in 1399 AD to spread Islam on Java [2]. Since its creation, other pesantren have been established. Therefore, it has become a part of Indonesian education for a long time [3]. It is a community of life consisting of education, teaching, and community development [4].

According to Rahim [5],Pesantren is an educational institution that has been part of the lives of Indonesian people for hundreds of years. As an institution, it is unique with distinctive characteristics and its ability to last for a long time shows that it has the capability to deal with the existing plurality of polemics. According to historical records, pesantrencontributessignificantly to educating and enlighteningthecommunitywiththeability createintellectualinstitutionsthat are comparable to formal schools [6].

LintangSongo Islamic Boarding School is among the traditional pesantren that has been in existence with consistency in carrying out its social functions. Its unique feature lies in the entrepreneurship education for students and the surrounding community [7]. Three learning models are optimized, namely religious (general learning in all pesantren), science (formal learning according to its level), and self-reliance and social learning [8].

Since its establishment, the school not only functioned as an educational institution but also as a social change and community empowerment agent [9]. It also serves to convey Islamic science and values carry out social control and engineering [10]. According to Qomar, pesantren are actively involved in community welfare mobility. Similarly, Ma'sum stated that it comprises of three main functions, namely religious, social, and educational [11].

Entrepreneurship training should be exemplified by educational institutions or other schools in Indonesia. Regarding modernization, it tends to perform its function to empower community self-reliance. The pesantren must be able to create human resources consisting of religious and entrepreneurship knowledge, with the ability to empower people to possess entrepreneurial these skills at the same time [12]. The Percentage of entrepreneurship and community empowerment data [13]. 
Business Units And Community Empowerment At The Lintang Songo Islamic Boarding School of Yogyakarta

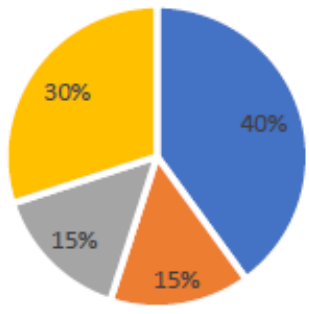

- Agriculture " Home Industry - Convection = Others

Presently, there are no other studies has been found related to Entrepreneurship Education as Community Empowerment. However, the author was able to determine some similarities between this study and previous studies, as follows: The first was found in, MangunBudiyanto and Imam Muchali (2014) in a journal entitled "Establishment of the Character of Self-reliance through Agriculture Education at the LintangSongo Boarding School of PiyunganBantul Yogyakarta

(PembentukanKarakterMandiriMelaluiPendidikan

Agriculture di PondokPesantren Islamic Studies Center AswajaLintangSongoPiyunganBantul Yogyakarta) [14].

The second is UyuWahyudin (2012) in a journal entitled "Eco-cultural Background Entrepreneurship Training for the Empowerment of Rural Poor." The third was found in Abdul Malik and Sungkowo Edi Mulyono (2017) journal entitled "Local Potential-Based Entrepreneurship Development through Community Empowerment (PengembanganKewirausahaanBerbasisPotensiLokalmelal uiPemberdayaanMasyarakat) [15].

Fourth, is in a journal entitled "Poverty Alleviation through the Social Entrepreneurship Approach" written by NurFirdaus (2014). The fifth is found in Nuryetty Zain, et al. (2017) journal entitled "Entrepreneurship Socialization and Children's Education between e-commerce and parenting in the Digital

(SosialisasiKewirausahaandanPendidikanAnak

Age

Bisnis On Line danMengasuh di Era Digital) [16].

While the sixth was written by EntohTohani (2015) in a journal entitled "The Impact of Community Entrepreneurship Education (PKUM) in the Context of Community Empowerment

(DampakPendidikanKewirausahaanMasyarakat (PKUM) DalamKonteksPemberdayaanMasyarakat) [17] The seventh was by Azel Raoul Reginald and ImronMawardi (2014) in a journal entitled "Social Entrepreneurship in Sidogiri Islamic Boarding School of Pasuruan." Eighth, Eni Riwayati (2015) in a journal entitled "Self-reliance Education at LintangSongo Islamic boarding school in Bantul, Yogyakarta (PendidikanKemandirian Di PondokPesantren Islamic Studies Center AswajaLintang Songo PiyunganBantul Yogyakarta) [18]. These previous studies are more directed to entrepreneurial training and development, leading to the development of the economic potential of the community. In addition, this research also focuses on the practice of Entrepreneurship education initiated by the LintangSongoAswaja Islamic Boarding School, which highlighted the community empowerment program carried out through Entrepreneurship training and education. It focuses on the study of self-reliance community empowerment programs at this institution. However, it is one of the modern pesantren that has practiced social activities with community empowerment programs through Entrepreneurship education.

\section{RESEARCH METHOD}

The place of this research is LintangSongo Islamic Boarding School located in Yogyakarta Indonesia.This study aims to find out more about the role of the LintangSongo Islamic Boarding School in economic empowering of its students and community. To achieve these goals, this field research uses qualitative methods in analyzing data. Meanwhile, data obtained by observation, documentation and interviews. The informants of this study consisted of 12 people, from the head of the LintangSongo Islamic Boarding School, the teachers, students and the community. Several questions were asked to informants, such as what economic empowerment program was developed at LintangSongo Islamic Boarding School, why LintangSongo Islamic Boarding School developed economic empowerment education. The answers to these questions are then analyzed using qualitative methods.

\section{RESULT AND DISCUSSION}

1. Overview of LintangSongo Islamic Boarding School

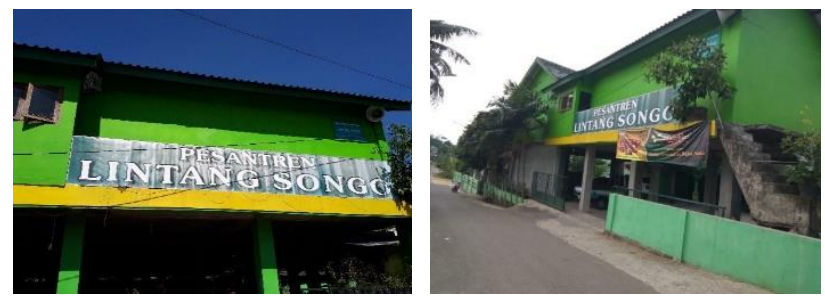

Figure 1: The front yard of the LintangSongo Islamic Boarding School

The Islamic Boarding School is located in Pager Gunung 1, RT 1 Sitimulyo Village, Piyungan District, Bantul Regency Special Region of Yogyakarta. The pesantren which began in 1991 by KH.Heri was inaugurated 2006 [19].

Its development and construction as a center of religion and community social activities through entrepreneurship training affected the economic development of the surrounding community. This is because it developed entrepreneurship skills and provided business capital [20]. The author argues that its establishment involves the cooperation of many parties. Entrepreneurship education in various fields in the pesantren involves alumni from UGM, UNY and some Islamic boarding schools in Yogyakarta. The training and entrepreneurship education activities have received a lot of government appreciation and attention, including from the former President of the Republic of Indonesia, Susilo Bambang Yudhoyono [21]. It consists of 70 students (43 male and 27 female) and six teaching staff. Most of the students are orphans or come from poor families, from various regions in Indonesia (Aceh, Tapanuli, Medan, Padang, Palembang, Lampung, Banten, Jakarta, NTT, Kalimantan, Ambon, Central Sulawesi, Jepara, etc.).

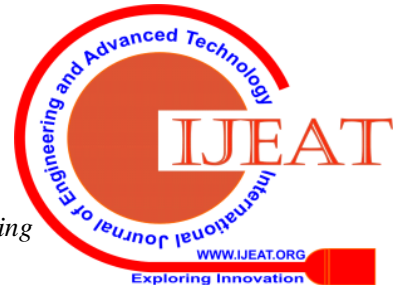


However, this is not a criterion as anyone can be a student there, starting from elementary school children to graduates [22]. Based on the above elaboration, it is understood that the empowerment activities of students and self-reliance-oriented of the community are the results of the collaboration between the pesantren educators and various parties.

\section{Pesantren and Community Economic Empowerment}

Islamic boarding schools are character building institutions withnumerous advantages in transforming science-intensive theology. Since the pre-independence until now, it hasplayed an essential role in realizing the independence and development of Islam in Indonesia. Presently, they are demanded not only to be oriented towards religious studies and formal education but to create skilled human resources and benefit the surrounding environment [23].

Islamic boarding schools have a strategic role in fostering students in studying the Islamic sciences. Also, it teaches about self-reliance and community economic empowerment. Islamic boarding schools as "cultural institutions" are established from community initiatives which are autonomous. Initially, most pesantren were educational and religious institutions, however, currently, some of having tried to reposition themselves in addressing various social issues, such as economics, social affairs, and politics [24].

According to Sumodiningrat, economic empowerment is an effort to create a strong, modern, and highly competitive economy in the right market mechanism. Community economic development requires structural change, capital, economic skills, education, as well as protection and support [25].

According to the author, it is not only oriented to religious literature but also contributes to the society through entrepreneurship education, which is a life skill that helps students after graduating from the pesantren.

\begin{tabular}{|c|c|c|c|} 
ACTIVITIES UNITS IN LINTANG SONGO ISLAMIC \\
BOARDING SCHOOL \\
\hline No & Time & $\begin{array}{l}\text { Activiti } \\
\text { es }\end{array}$ & \multicolumn{1}{|c|}{ Description } \\
\hline 1. & $\begin{array}{l}07.00- \\
17.00\end{array}$ & $\begin{array}{l}\text { School/ } \\
\text { college }\end{array}$ & $\begin{array}{l}\text { Those who did not attend any } \\
\text { educational institution will } \\
\text { recite the Koran and } \\
\text { undergo skills acquisition }\end{array}$ \\
\hline 2. & $\begin{array}{l}\text { Fajr and } \\
\text { Maghrib }\end{array}$ & $\begin{array}{l}\text { Koran } \\
\text { recitati } \\
\text { on }\end{array}$ & $\begin{array}{l}\text { Study Unit: Tawheed, Fiqh, } \\
\text { Morals, history, Al-Qur' an } \\
\text { and KitabKuning }\end{array}$ \\
\hline 3. & $\begin{array}{l}\text { Afternoo } \\
n\end{array}$ & $\begin{array}{l}\text { Skills } \\
\text { Skill units: Agriculture, } \\
\text { Convection, Home Industry, } \\
\text { Fisheries, Forestry, and } \\
\text { others }\end{array}$ \\
\hline
\end{tabular}

Development, stabilization of attitudes, behaviors, abilities, and interests in entrepreneurship are the efforts needed to realize self and economic resilience. Entrepreneurship drives the economy of the community and accelerates national growth. This effort requires support from the government, the community, and the business world in a directed and sustainable manner [26].

The process of learning by practical such as in agriculture, fisheries, forestry, convection, etc., shows the transformation of technical skills acquired by the students. Recently, it has become imperative to analyze the role of pesantren in the community economic empowerment because it is a source of new inspiration for facing modern challenges [27]. Therefore, knowledge and skills are part of the instruments in achieving work competencies. The effort to empower community self-reliance is the duty and responsibility of the government and local institutions or organizations (like pesantren) [28].

\section{LintangSongo Islamic Boarding School as the Center of Community Economic Empowerment}

\section{a. Empowerment in Agriculture}

The School makes some entrepreneurial activities a source of funds for all its social and religious activities. It provides free education and boarding facilities to all students. More than 36 million rupiahs is required every month per month to meet the bills associated with food, electricity, internet, etc. However, agricultural products are used entirely to meet the daily basic needs of students and the community.

\section{b. Empowerment in the Convection Sector}

It provides convection training for students and the community so that they can become entrepreneurs. This effort has been properly carried out, in such a way that students and trainees illustrate self-reliance outside the pesantren[29].

However, the students and community are constrained by the capital to open a convectional business. Ideally, pesantren does not only provide education but the initial capital assistance.

\section{c. Empowerment in the Field of Home Industry and Washing Soap}

It is an education partner for the community in every social activity. Since its inception, it has been empowering home industries with various community needs.

This is in line with the goal of empowerment, which is based on the ability to recognize the real needs of the community. It provides training and entrepreneurship education to make its surrounding environment self-reliance. Besides, the home industrial products are sold in several shops in Yogyakarta, and the results used entirely to meet the needs of the boarding schools [30].

\section{CONCLUSION}

LintangSongo Islamic boarding school succeeded in empowering economy of its students and communities with entrepreneurship education.Entrepreneurshipeducation is included in the boarding school curriculum and it is taught to all students and the local communities.Economic empowerment conducted by LintangSongo Islamic Boarding School for its students and community is agricultural empowerment, plantations, animal husbandry, forestry, fisheries, home industry, food, and convection. 


\section{REFERENCES}

1. Mastuhu, DinamikaSistemPendidikanPesantren, (Jakarta: INIS, 1994), 55.

2. Ronald Alan Lukens Bull, A Peaceful Jihad: Javanese Education and Religion Identity Construction, (Michigan: Arizona State University, 1997), 60.

3. Mastuhu, DinamikaSistem..., 7.

4. SoetjiptoWirosardjono, The Impact of Pesantren in Education and Community Development in Indonesia (Berlin: Fredrich-NaumannStiftung. Indonesian Society for Pesantren and Community Development (P3M), and Technical University Berlin, 1987), 218.

5. Husni Rahim, PesantrendalamSebuahWacana (Yogyakarta, PustakaPelajar, 2002), 21.

6. Gusnadi,

"UapayaPondokPesantrenSalafDalamPemberdayaanMasyarakat (Case Study About At-Taufiq Islamic Boarding School and Malang)," Jurnal of Islamic Education, Volume III, Edisi 1, 2017, hal 350

7. Integrated System di Pesantren ISC AswajaLintangSongo Yogyakarta,

http://www.nu.or.id/post/read/56384/integrated-system-di-pesantrenisc-aswaja-lintang-songo-yogyakarta on Thursday the 21st of 2019 at 09.40pm

8. Integrated System di Pesantren ISC AswajaLintangSongo Yogyakarta,

9. Anwar

ArifWibowo,

"StrategiPondokPesantrenDalamMenumbuhkanSemangatJiwaKewir ausahaanMasyarakat (Study at the LintangSongo Islamic Boarding School of Bantul)," Thesis, Yogyakarta: UIN SunanKalijaga, 2015

10. DirektoratPendidikanKeagamaandanPondokPesantrenDitjenKelemb agaan Agama Islam Dapertemen Agama RI, PedomanPengembanganPesantren and PendidikanKeagamaan 2004-2009, (Jakarta: 2004), 8

11. MujamilQomar,

PesantrendanTranformasiMetedologiMenujuDemokrasi Institute, (Jakarta: Erlangga, 2002), 23

12. MangunBudiyanto and Imam Muchali, "PembentukanKarakterMandiriMelaluiPendidikan Agriculture di PondokPesantren Islamic Studies Center AswajaLintangSongoPiyunganBantul Yogyakarta," Journal of Character Education, Vol. IV, No. 2, (2014)

13. Results of Interview with KH. Heri, Caregiver of ISC LintangSongo Islamic Boarding School, April 10, 2019, and Document of LintangSongo Islamic Boarding School

14. MangunBudiyanto and Imam Muchali, "PembentukanKarakterMandiriMelaluiPendidikan Agriculture di PondokPesantren Islamic Studies Center AswajaLintangSongoPiyunganBantul Yogyakarta," Character Education Journal, Vol. IV, No. 2, (2014)

15. Abdul Malik and Sungkowo Edi Mulyono, "PengembanganKewirausahaanBerbasisPotensiLokalmelaluiPember dayaanMasyarakat," Journal of Informal Education and Community Empowerment, Vol. 1, No. 1 (2017)

16. Nuryetty Zain, et al. "SosialisasiKewirausahaandanPendidikanAnak Antara Bisnis On Line danMengasuh di Era Digital," Journal of Civil Society Empowerment (JPMM), Vol. 1, No. 2 (2017), 276

17. EntohTohani, "DampakPendidikanKewirausahaanMasyarakat (PKUM) DalamKonteksPemberdayaanMasyarakat," Scientific journals, Vol. 10, No. 1 (2015)

18. Eni Riwayati, "PendidikanKemandirian Di PondokPesantren Islamic Studies Center AswajaLintangSongoPiyunganBantul Yogyakarta," Thesis, Yogyakarta: UIN SunanKalijaga, 2015

19. Documentation of the LintangSongo Islamic Boarding School

20. Interview with $\mathrm{KH}$ Heri, Educator of the LintangSongo Islamic Boarding School, April 10, 2019

21. LintangSongo Islamic Boarding School of Bantul, taken from http://www.nu.or.id/post/read/43550/pondok-aswaja-lintang-songobantul on Thursday, 212019 at 9:15 p.m.

22. Interview with KH Heri, Educator of the LintangSongo Islamic Boarding School, on April 10, 2019

23. Moh. Toriquddin, "PemberdayaanEkonomi Di PesantrenBerbasisSyariah," De Jure: Journal of Law and Sharia, Vol. 3, No. 1 (2018)

24. TirtaRahayuNingsih,

"PemberdayaanEkonomiPesantrenMelaluiPengembanganSumberDa yaLokal," LembaranMasyarakat: Islamic Community Development Journal, Vol. 3, No.1 (2017)
25. Mohammad Nazir, "MembangunPemberdayaanEkonomi Di Pesantren," Economica: Journal of Islamic Economics, Vol. 6, No. 1 (2015), 40

26. Rudi

Haryanto, "MenumbuhkanSemangatWirausahaMenujuKemandirianEkonomiU matBerbasisPesantren," Nuansa: Research Journal of Social and Islamic Sciences, Vol. 14, No. 1 (2017), 204

27. Rizal Muttaqin,

"KemandirianAndPemberdayaanEkonomiBerbasisPesantren," Journal of Indonesian Islamic Economics, Vol. 1, No. 2 (2011), 75-77

28. ayokRimbawan, "PesantrenAndEkonomi," Conference Proceedings. Annual International Conference Islamic Studies (AICIS), XII, (2012)

29. Interview with $\mathrm{KH}$ Heri, Educator of the LintangSongo Islamic Boarding School, on April 10, 2019

30. Interview with $\mathrm{KH}$ Heri, Educator of the LintangSongo Islamic Boarding School, on April 10, 2019

\section{AUTHORS PROFILE}

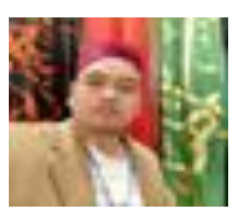

Muhammad Roy Purwanto, was born in Magelang April 25, 1978. He studied at the Universitas Islam Indonesia (bachelor), Islamic State University SunanKalijaga (Master) and Islamic State University SunanKalijaga (Doctoral program). His publications areis Religious Learning with Social Media and Its Implication for Understanding Religionin International Journal of Engineering and Advanced Technology, Volume-8 Issue-6S3 (September 2019), Sultan Agung's Thought of Javanis Islamic Calender and Its Implementation for Javanis Moslem (International Journal of Emerging Trends in Social Sciences, 2018), Islam and State (Book, 2018), Science of Logic (book, 2018), Mapping of Religious Thought and Radical Idiology for Higher Education Lecturer in Indonesia (proceeding, 2017), Maqashid al-Syari'ah and Legal Maxim as Sourse of Medical Action (Proceeding, 2017), Problem of Muslim Minorities in Allahabad India and Bali Indonesia (Proceeding, 2017), Acculturation between Islam Theaching and Javanese Culture in Mubeng Beteng Ritual Among Moslem in Yogyakarta (Proceeding, 2017), Different Qiraat and Its Implication in Different Opinion of Islamic Jurisprudence (An-Nur Journal, 2017), Shafi'i'sThoughon Qiyas and Its Implication in Islamic Jurisprudence (Book, 2017),Ibn Qayyim's Theory on Fatwa and Its Implication in Developing Islamic Law (book, 2017), Reformulation of Maslaha Concept as Pilar of Islamic Law (book, 2017), Acculturation among Local Wisdom, Law and Sufism in Forming Martabat Tujuh Enactment of Buton Sultanate (International Journal of Humanities and Management Sciences, 2016), Theory of Islamic Jurisprudence and Multiculturalism (book, 2016), Dekonstruction of Philosophy of Islamic Jurisprudence: Najmuddin al-Thufi's Concept of Maslaha as Method of Islamic Law (book, 2008), Ushul Fiqh in Aristotle's School: The Influence of Aristotelian Logic in Sillogisme Theory of Ushul Fiqh (book, 2005), Islamic Thought and Civilisation (Book, 2004), His research work are Reconfiguring Islam, State and Religious Freedom in Indonesia and Tunisia (Ministry of Religious Affair, 2019), Trend of exclusivism and radicalism of Indonesian students in Egypt, Australia and Malaysia(Ministry of Religious Affair, 2019), Mapping of Religious Thought and Radical Idiology for Higher Education Lecturer in Indonesia (Ministry of Education, 2019, 2018, 2017), Implication of Aristotelin Logic in Structure of Islamic Studies (MoRA, 2017), Acculturation among Local Wisdom, Law and Sufism in Forming Martabat Tujuh Enactment of Buton Sultanate (UII, 2016), Mut'ah Mariage and Its Implication For Moslem Society (MoRA, 2015). Now he is Assosiate Profesor at Universitas Islam Indonesia, Yogyakarta, Indonesia.

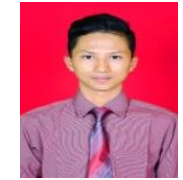

Supriadi, was born in Padang Sawah 13 Mei, 1998. He is student at faculty of Islamic studies, Universitas Islam Indonesia. He is editor of the Student Journal of Faculty of Islamic Studies: at-Thullab. His publication is Religious Learning with Social Media and Its Implication for Understanding Religionin International Journal of Engineering and Advanced Technology ,Volume-8 Issue-6S3, (September 2019). 
RahmaniTimoritaYulianti, was born in Kupang, 27 Juli $1964 \mathrm{He}$ studied at the Universitas Islam Indonesia (bachelor),Islamic State UniversitySyarifHidayatullah Jakarta (Master) and Islamic State University Sunan Kalijaga (Doctoral program).His publications areEconomic Performance AchievementWoman: Experience in Indonesia " GEOGRAFIA online Malaysian Journal of Society and Space, Vol. 9 issue 4, ISSN 2108-2491 (2013), A Critical Review AboutThe Role of Leadership in BuildingProfessionalism of Zakat Institutions "GEOGRAFIA online Malaysian Journal of Society and Space, Vol. 10 issue 2 ISSN 2108-2491(2014). Journal of "Insemination of Inner ValuesEconomics Lessons at Madrasah AliyahNegeri III Yogyakarta ", TAPIS JournalJournal of Scientific Research Vol. 15, No. 01.January-June 2015. Journal "Efforts of Amil Zakat Institutions andInfa on Attracting Community Interest:Review of Zakat Fund Management andInfa by the Kita Smile Foundation atYogyakarta "LIFEWAYS International Journal Of Society Development and Environtment in the Developing Word, Volume 1, Issue 2 (2017). Book: "Good Corporate Governance inZakat Institutions "(2016). Book: "Empowering the Economic CommunityMosque Based: A Synergistic Effort " (2017).E-mail (Home): rahmanitimorita@uii.ac.id 